\title{
Perioperative Management for the Patients with Obstructive Sleep Apnea
}

\author{
Jeong Heon Park, Min A Kwon \\ Department of Anesthesiology and Pain Medicine, Dankook University Hospital, Cheonan, Korea
}

\section{폐쇄성 수면무호흡 환자의 주술기 관리}

박정헌, 권민아

단국대학교병원 마취통증의학교실

\begin{abstract}
Received January 1, 2021
Revised March 11, 2021

Accepted March 29, 2021
\end{abstract}

Address for correspondence Min A Kwon, MD, PhD

Department of Anesthesiology and Pain Medicine,

Dankook University Hospital,

201 Manghyang-ro,

Dongnam-gu, Cheonan 31116

Korea

Tel: +82-41-550-6814

Fax: +82-41-550-6814

E-mail: mmauss73@gmail.com, mmauss73@dankook. ac.kr
The prevalence of obstructive sleep apnea (OSA) is on the rise worldwide due to an increase in metabolic syndrome, obesity, and aging. Patients with OSA are at higher risk of perioperative complications than those without OSA; however, OSA is often not diagnosed before surgery. For patients diagnosed with OSA or who are judged to be at risk of OSA by various screening tools, safe preparation for respiratory depression or difficult airway is critical. Exaggerated respiratory depression often occurs in response to commonly used sedatives and analgesics, and there is a high risk of hypoxic events due to difficulty in maintaining the airway. Currently, there is insufficient training of health care providers to screen and diagnose patients with OSA, and several screening tools are incomplete. In addition, the guidelines for optimal monitoring and perioperative management of patients with OSA have not yet been clearly established. In the present work, the author aims to explain the latest findings useful to sleep physicians regarding the overall management, including pre-operative evaluation and preparation, intraoperative anesthetic management, and post-operative general care and analgesic strategies, of patients at risk of OSA.

J Sleep Med 2021;18(1):12-21

\section{서 론}

폐쇄수면무호흡(obstructive sleep apnea, OSA)은 비만인 구 증가, 고령화 및 대사질환의 동반 등으로 전세계적으로 증 가추세에 있다. ${ }^{1}$ 전체 인구에서 OSA의 유병률은 9 38\% 정 도이며 남성에서 많고, 나이가 증가함에 따라 급증하여 고령 에서는 80 90\%에 달한다고 보고되기도 한다. 일반적인 정규 수술환자의 20 40\%의 환자가 OSA의 위험군에 해당한다. ${ }^{2}$ 비만도가 적은 아시아권에서도 식습관 변화 등으로 인해 비 만인구가 꾸준히 증가되고 있어, Sunwoo 등의 최근 보고에 따르면, 한국인에서도 OSA 위험환자의 유병율이 $15.8 \%$ 에 달하며 고령, 비만 등이 유의한 위험인자였으며 정상 신체

This is an Open Access article distributed under the terms of the Creative Commons Attribution Non-Commercial License (https://creativecommons.org/licenses/by-nc/4.0) which permits unrestricted non-commercial use, distribution, and reproduction in any medium, provided the original work is properly cited.
활동을 유지할 경우 감소하는 경향을 보였고, 당뇨, 고혈압, 고지혈증 등 대사질환들과 유의하게 동반되었다. ${ }^{3}$

자각 증상이 없어 진단되지 않은 OSA 환자라도 주술기 위 험을 유의하게 증가시킬 수 있다. OSA 환자에 다양한 정도 로 동반되는 저산소증, 어려운 기도유지 및 수술 후 아편유 사제 유도성 호흡억제(opioid induced respiratory depression, OIRD)는 종종 환자의 사망과 여러 합병증을 초래할 수 있 다. ${ }^{4}$ 이에 수술 전 OSA에 대한 대비가 중요한 수술 전 환자관 리로 강조되고 있으며, 주술기 동안 OSA 환자에 대한 안전한 예방 및 관리방법에 대해 근거 중심으로 기술해 보고자 한다.

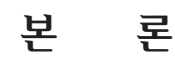

\section{$\mathrm{OSA}$ 의 정의}

OSA는 수면장애에 대한 국제 분류(International Classi- 
fication of Sleep Disorders) 진단 기준에 따라 수면다원검사 결과를 토대로 진단한다. 수면다원검사에서 호흡장애지수 [(respiratory disturbance index, RDI) $=($ 무호흡 + 저호흡 + 호 흡노력각성)의 횟수/수면 시간가 5 이상이면서 주간졸림, 피 로, 자고 나도 개운치 않은 불면증 증상과 코골이 및 수면무 호흡 관찰 중 하나만 있으면 진단할 수 있다. 또한, 환자에게 관련 증상이 없어도 수면호흡장애지수가 15 이상이면 OSA 로 정의한다. OSA의 정도는 수면다원검사를 통해 시간당 무 호흡-저호흡 지수(apnea-hypopnea index, AHI)에 따라 정 상 $(\mathrm{AHI}<5)$, 경도 $(5 \leq \mathrm{AHI}<15)$, 중등도 $(15 \leq \mathrm{AHI}<30)$, 중 증(AHI $\geq 30)$ 으로 나뉘며, 호흡장애지수와 혼용하여 사용하 기도 한다. OSA는 수면 중 상기도의 완전 또는 부분적 폐쇄 로 인하여 공기 흐름의 제한, 정상 수면의 단절, 산소 포화도 감소, 고탄산혈증, 흥곽 내 압력 변동과 교감신경 활성 증가 등을 야기시킴으로써 주간 삶의 질을 저하시키며, 인지 기능 저하 및 심뇌혈관 합병증과 대사 장애의 원인이 된다. 5,6

\section{OSA와 관련된 주술기 위험}

어려운 기도(Difficult airway)

어려운 기도를 결정하는 가장 중요한 해부학적 구조는 혀 기저부를 안착시킬 충분한 아래턱 공간(mandibular space) 이 있는지에 달려있다. OSA는 잠들거나 의식이 저하될 때, 혀 기저부의 긴장도가 떨어지며 비인두의 후벽을 막아서 발 생하게 된다. 이때, 혀 기저부가 시작되는 아래턱 공간이 충 분한 경우(Fig. 1A)에는 혀의 상당부분이 아래턱 공간에 위 치하기 때문에 기도를 막는 횟수와 정도가 약하다. 그러나, 턱의 발달이 적은 작은턱증(micrognathia) 등 충분한 아래턱 공간이 없는 경우(Fig. $1 \mathrm{~B}$ ), 혀 기저부는 기본적으로 뒤쪽과 위쪽으로 밀려 올라가 있는 상태이며, 의식이 저하되거나 수 면 중에 혀의 긴장도가 떨어지면 기도가 심하게 막히게 된다. 이 때, 턱을 들고(chin up), 머리를 젖히고(neck extension), 턱을 들어올리는(jaw thrust) 등의 여러 시도를 하게 되나, 기 도를 막고 있는 혀를 들어올릴 공간이 없는 상태이므로 교 정하기 힘들다. 즉, 해부학적으로 기도확보가 어려우며, 어려 운 기도삽관의 경우가 된다. Mallampati 분류에서 단계가 높 을수록 목젖(uvula)에 대한 혀의 위치가 점차 높이 차올라오 는 정도를 구별할 수 있을 것이다(Fig. 2). 경험이 많은 임상 의사라면 진료실에 들어서는 환자의 옆모습만 보아도 턱의 발달정도와 기도 삽관의 위험도를 미루어 짐작할 수 있다.

비만과 어려운 기도와의 상관관계에 대해서는 많은 연구 가 있어왔다. OSA 환자의 경우, 비만으로 인한 인후두부 조 직의 비후로 공간이 협소하고 근육의 긴장도가 떨어져 어려

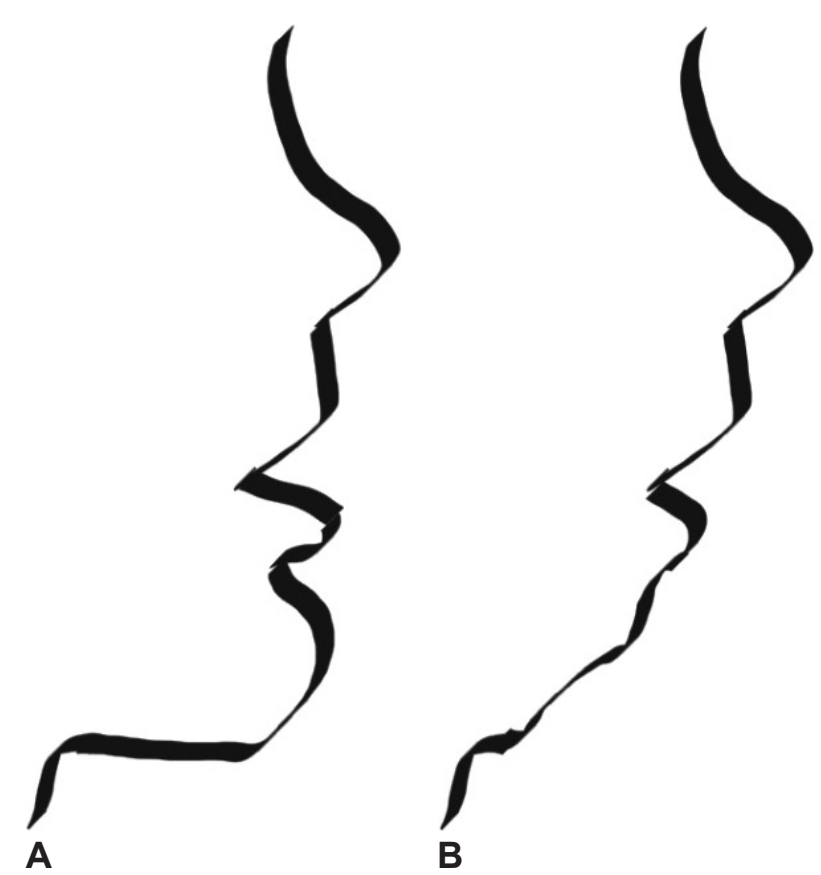

Figure 1. Comparison of lateral facial features between patients with normal mandible structures and micrognathia patients. (A) Normal mandible. (B) Micrognathia.

운 마스크환기(difficult mask ventilation)가 되기 쉽다. ${ }^{8}$ 특히, 수면이나 진정 등의 상황에서 신경근 활동이 감소되면 기도 를 열어주는 이완근의 힘을 상쇄하는 기계적 부하가 걸리게 된다. 그런데, OSA가 어려운 마스크 환기와 관련성이 크다 고 보고된 많은 연구가 있었지만, ${ }^{9-11}$ 실제 어려운 기도 삽관 의 위험인자 인지는 논란이 있다. 유의한 상관성이 있다는 연 구도 있지만, ${ }^{911}$ 많은 연구에서 기도 삽관의 위험성과는 상관 관계가 명확하지 않다고 보고되고 있다., ${ }^{82-14}$ Neligan 등도 병적 비만, OSA 그리고 목둘레가 어려운 기도 삽관에 미치 는 영향을 연구하였다. ${ }^{12}$ 평균 체질량지수(body mass index, BMI) $50 \mathrm{~kg} / \mathrm{m}^{2}$ 정도의 병적 비만환자 180 명에서 OSA의 유 병률은 $68 \%$ 였고, AHI는 31.3이었다. 모든 기도 삽관은 마취 과 전공의에 의해 수행되었으며, 3 번 이상 시도해야 하는 어 려운 삽관 유형은 $3.3 \%$ 였다. 흥미롭게도 비만도와 OSA, 목 둘레 길이 중 어떤 것도 어려운 기도 삽관과 유의하게 관련 되지 못했다. 남성 성별과 Mallampati 분류 3 이상일 경우에 만 유의한 상관관계가 있었다.

그러나, 동반된 비만으로 인해 마스크 환기가 어렵고 빠른 속도로 산소 포화도가 감소하는 상황에서 기도 삽관을 수행 하는 의사의 부담은 매우 크다. 어려운 기도 삽관 환경까지 더해져 여러 번 삽관 시도를 해야 하는 상황이라면 삽관이 성 공하더라도 환자의 기저질환의 상태에 따라 사고가 동반될 위험이 크다. 따라서, 전체적으로 OSA 환자는 OSA가 없는 환자에 비해 어려운 기도관리에 대한 위험이 높다고 간주되 

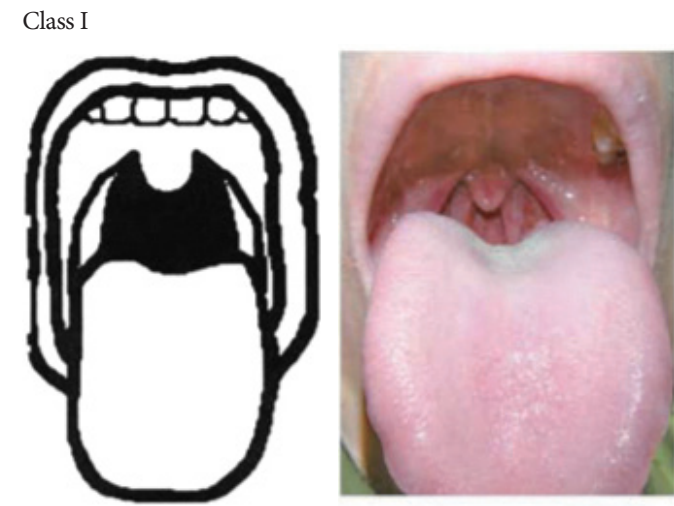

Class III

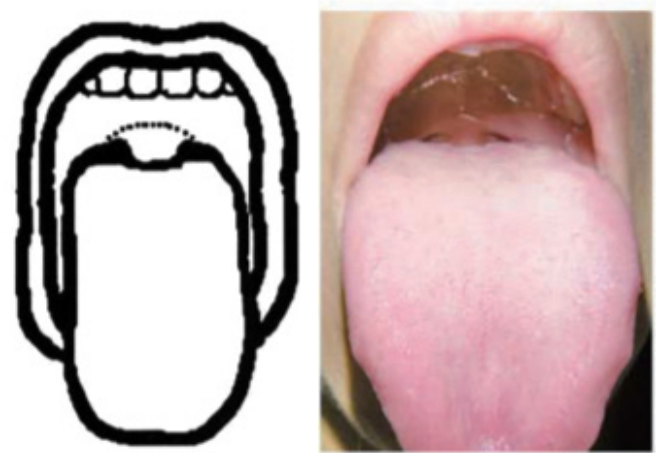

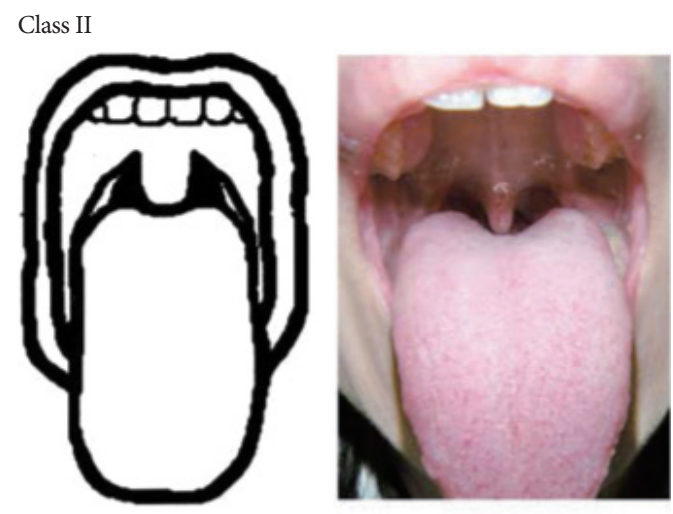

Class IV

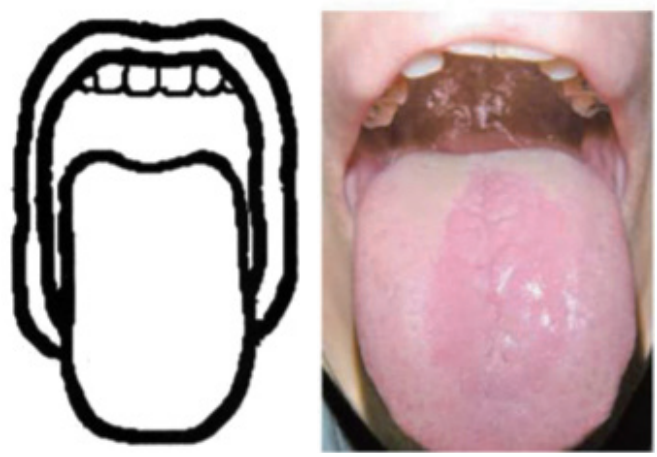

Figure 2. Mallampati classification. As the Mallampati score increases, the position of the tongue relative to the pharyngeal wall gradually rises upward. Adapted from Huang et al. BMC Gastroenterology 2011;11:12.

어야 하며, ${ }^{8,15}$ 어려운 기도에 대한 수술 전 철저한 준비와 예 방이 필요하다.

\section{저산소혈증(Hypoxemia)}

비만환자는 정상인에 비해 신체 대사를 위해 많은 산소요 구량을 가진다. 그러나, 이런 요구를 충족시킬 수 있는 산소 공급을 위한 호흡역학은 감소되어 있다. 동반된 비만정도에 비례하여 폐활량(vital capacity)과 총폐용적(total lung capacity)의 감소를 보이지만 중증 OSA에서도 폐활량이나 총 폐용적은 정상범위 내를 유지한다. ${ }^{16}$ 그러나 기능성 잔류 용 량(functional residual capacity, FRC)과 호기 예비 용적(expiratory residual volume, ERV)이 BMI가 증가함에 따라 기 하 급수적으로 감소하여 잔존 용적(residual volume, RV) 근 처에서 호흡하게 된다. 즉, 중심성 저환기(central hypoventilation)의 영향이 아니라 폐기능의 변화로 인한 빠르고 심한 저산소혈증이 발생하게 된다. 또한, 이런 폐기능 감소가 병적 비만에서만 심하게 발생하는 것이 아니라 과체중이나 BMI $30 \mathrm{~kg} / \mathrm{m}^{2}$ 정도의 약한 비만에서도 크게 나타난다는 특징이 있다. $\mathrm{BMI} 30 \mathrm{~kg} / \mathrm{m}^{2}$ 일 때 $\mathrm{FRC}$ 는 정상인의 $75 \%$, ERV는 정 상인의 $45 \%$ 까지 감소한다. ${ }^{16}$

자세에 따른 영향도 크다. 앙와위나 Trendelenburg 자세에
서 비만한 복강내 장기의 위치이동에 의해 폐 기저부는 쉽게 허탈된다. ${ }^{16}$ 무기폐가 발생하고 더욱더 $\mathrm{FRC}$ 와 $\mathrm{ERV}$ 가 감소 하게 되며 폐쇄용적 내 호흡이 이루어지고 저산소혈증이 악 화된다. 기관내 튜브의 위치도 깊어져 일측폐환기가 될 수 있 으므로 최종 위치로 자세 변경 후 재확인해야 한다. 수술 후 폐합병증을 감소시키기 위해 금기가 없다면 상체를 높이는 역 Trendelenburg 자세를 취하는 것이 필요하다. ${ }^{17,18}$

\section{동반 질환 및 합병증 위험 증가}

$\mathrm{OSA}$ 는 장기적으로 건강에 악영향을 미치며, 수술 전후 합 병증 위험 증가와 관련이 있다. ${ }^{19} \mathrm{OSA}$ 환자에서 가장 뚜렷하 게 구별되는 병태생리는 간헐적인 저산소혈증(intermittent hypoxemia)이다. 자주 반복되는 저산소혈증은 신체 내의 반 응산소종(reactive oxygen species)을 증가시키고 단핵구의 염증성 물질의 분비를 증가시켜 만성 염증 상태를 초래한다. 이로써, $\mathrm{OSA}$ 는 심혈관 질환과 당뇨나 고지혈증 등의 대사 성 질환의 증가와 관련이 있고, 교감신경을 항진시키고 수면 의 질을 더욱 낮추는 악순환에 빠진다. 신장 기능장애와 뇌 혈관에도 부정적 영향을 가진다. ${ }^{20}$

수술 후 아편유사제를 사용하는 OSA 환자는 수술 전후 심 혈관 합병증의 증가와 유의한 상관관계를 가진다. ${ }^{21}$ Chan 등 
의 연구에 따르면 OSA가 있을 경우, 그리고 OSA의 중증도 가 클수록 30 일 중증 심혈관 합병증의 발생률이 유의하게 증 가하였다. ${ }^{5}$ 그러나, 중증 OSA는 심혈관 질환 합병증을 증가 시키나, 경증에서 중등도의 OSA는 심혈관 합병증을 증가시 키지는 않았다. 마취 유형, 수술 후 아편유사제 사용 및 산소 보충 요법에서 수술 전후 결과에 대한 유의한 상호 작용 효 과는 관찰되지 않았다. OSA를 줄이는 치료적 개입이 심혈관 합병증의 발생을 줄일 수 있는지는 더 연구가 필요하다.

또한, OSA는 뇌혈관질환의 발생을 증가시킨다. Dong 등 의 연구에 따르면 뇌혈관질환자에서의 OSA 유병률은 무려 $61 \%$ 나 되며 이중 $30.1 \%$ 에서 $\mathrm{AHI}>30$ 의 중증 OSA를 동반 하였다..$^{22}$ 뇌혈관질환의 과거력이 있는 환자의 경우, 비만이 나 어려운 기도가 예상되는 상황이 아니더라도 심한 OSA가 발생할 수 있으므로, 모니터링과 안전한 약 용량 선정 등 섬 세한 환자관리가 요구된다.

\section{아편유사제 유발 호흡억제(OIRD)}

$\mathrm{OSA}$ 환자의 주술기 위험 중 가장 주의를 기울여야 할 것 중 하나가 OIRD이다. ${ }^{15} \mathrm{OSA}$ 는 고령, 비만, 동반된 심혈관 질 환이나 폐질환, 진정제 동반 사용 및 지속 주입형 아편유사제 사용 등과 함께 OIRD의 중요한 위험인자들 중 하나이다. ${ }^{4,15}$ 일반적으로 아편유사제는 과량 투약되었을 때 호흡 억제를 일으킬 수 있으나, OSA 환자는 중심 기전(central mechanism) 으로 유의하게 respiratory drive를 감소시키고 pharyngeal tone을 떨어뜨려 기도 폐색을 일으킨다. ${ }^{23}$ 또한, 기도 폐쇄로 인한 무호흡까지 동반되면 사망이나 중증 질환으로 이어질 수 있는 위험한 합병증이다. 아편유사제 사용량에 의존적으 로 발생하는 경우가 많으나, ${ }^{24,25}$ 2017년에 Subramani 등에 의 해 보고된 사망 사고 보고서에 따르면, 사망이나 사망 직전 까지 이른 환자에서 투여된 아편유사제 용량을 동등 모르핀 용량으로 환산했을 때 $81 \%$ 에서 하루 $10 \mathrm{mg}$ 이 안 되는 적은 양이었다. ${ }^{25}$ 즉, 아편유사제의 용량이 작더라도 치명적 합병 증이 발생할 수 있다는 것이다. 철저한 모니터링과 그에 따 르는 산소공급이나 지속기도양압(continuous positive airway pressure, CPAP) 및 기타 기구의 적정 시점에서의 사용, 그 리고 동시에 투약되는 진정제와 아편유사제 사용량 감소를 위한 복합 진통(multimodal analgesia)을 구상하는 등의 면 밀한 대비가 필요하다. ${ }^{26}$ 그러나 아직까지 아편유사제의 용량 증가가 폐합병증의 증가를 촉진시킨다는 근거는 충분하지 않다. ${ }^{27}$ 일부 연구에서 OSA 환자의 경우, 수술 직후 저산소 혈증의 위험이 증가되지만, 전체적으로 재원일수, 합병증 발 생, 중환자실 호흡기 거치 등의 예후인자에 오히려 도움이 되는 결과를 보인 바 있다. 따라서, OSA의 예후에 대해서는
좀더 정교하고 면밀한 연구가 필요할 것으로 생각된다.

\section{$\mathrm{OSA}$ 와 관련된 사망사고 분석}

2020년 Bolden 등은 전신 마취 또는 전신 마취와 국소 마 취를 결합한 시술을 받은 "OSA Death and Near Miss Registry"에 제출된 66건의 사망 및 중증 합병증 환자에 대한 분 석 연구를 발표했다. ${ }^{28}$ 환자의 $65 \%$ 는 사망하였고 $35 \%$ 는 심 각한 뇌 합병증이나 뇌사 판정을 받았다. 대부분의 환자가 수 술 전 OSA로 진단(83\%)되었거나 선별검사상 고위험군으로 분류되었다. 대부분 수술 후 24 시간 내 발생했으며, $56 \%$ 는 수술 후 병동에서, $21 \%$ 는 퇴원 후 집에서 발생하였다. 반 이 상의 환자에서 다양한 산소공급을 받고 있었지만, $\mathrm{CPAP}$ 등 의 사용은 $7.5 \%$ 에 불과했다. 환자의 $97 \%$ 에서 수술 후 24 시 간 내 다양한 용량의 아편유사제가 처방되었으며, 진정제와 함께 처방된 경우도 많았다(62\%). 사건이 목격되지 않았거나 부적절한 호흡 감시, 모니터 인력의 부재, 산소 공급의 부재, 아편유사제와 함께 진정제의 동시 사용 등이 유의한 위험인 자로 분석되었다. 흥미롭게도 이 보고에서 나이, 성별, 미국 마취과학회 환자분류, $\mathrm{OSA}$ 의 정도나 비만의 정도는 사고와 유의한 관계를 보이지 않았는데, 중증 사고의 보고수가 적은 것이 이유가 될 수 있을 것으로 생각되어진다. 심한 OSA의 유무가 중증 수술 후 합병증의 발생과 유의한 관련이 있음은 여러 대규모 연구를 통해 입증된 바 있다. ${ }^{5}$

특히, 저자들은 중증 사고의 $21 \%$ 가 수술 후 귀가 이후에 발생했다는 점에 특별한 주의를 기울일 것을 강조하고 있다. 수술이 간단할 경우 통원 수술 기반으로 진행되는 경우가 많 은데, 이런 감시되지 않는 상황이 OSA 환자들에게 매우 위 험한 환경일 수 있다는 점이다. 대부분의 중증 합병증은 수 술 후 24시간 내 발생하는데, 퇴원 후 가정에서 일어난 사고 는 대부분 미국마취과학회 환자분류 III-IV의 기저 질환자 였으며, 산소 공급이나 호흡을 감시할 인력이나 환경이 조성 되지 않았다. 반 이상의 중증 합병증 발생환자에서 산소를 사 용했고, $7.5 \%$ 의 환자에서 $\mathrm{CPAP}$ 를 사용했음에도 사망 등 중 증 합병증이 발생했다. 즉, 산소공급이나 $\mathrm{CPAP}$ 를 하더라도 가장 중요한 것은 호흡 모니터링이라는 것을 강조하고 있다. 회복실이나 준중환자실 혹은 중환자실은 중증 사건이 발생 하더라도 대부분 의료진에 의해 목격되어 처치되는 경우가 많고 합병증의 정도도 약했으나, 병동이나 가정에서 발생한 경우는 대부분 야간에 수면시간 중 발생하며 목격되지 못한 경우가 많았고 사망이나 뇌사 등 심각한 합병증을 초래하는 경우가 많았다. 최근 모든 OSA 위험환자군에서 저산소성 중 증 합병증을 예방하기 위한 호흡 모니터링의 필요성이 강력 히 권고되고 있다. ${ }^{29}$ 특히, 수술 후 24 시간 내 아편유사제 및 
진정제 처방 대상자라면 심한 OSA가 없더라도 맥박산소계 측기(pulse oximeter)와 날숨끝이산화탄소분압측정도(capnography) 등 감시장치를 24시간 동안 사용하는 것이 합병 증을 줄이는 데 중요하다는 연구가 많이 보고되고 있다. ${ }^{29}$ 날 숨끝이산화탄소분압측정도, ${ }^{4}$ 흥부 임피던스 그리고 호흡량 감시기 등은 진정진료 등에서 조기 호흡억제 발견 등의 효용 성을 입증하였으므로 앞으로 환자 감시 영역에서 다양하게 사용될 것으로 전망된다. ${ }^{30}$

\section{수술 전 환자평가 및 준비}

\section{수술 전 환자평가(Preoperative patient evaluations)}

수술 전 환자평가에서는 이전의 의료기록에 대한 종합적 인 검토, 환자 및 가족과의 면담 그리고 신체 검사 및 OSA 선별검사가 포함된다. ${ }^{31}$

\section{의료기록의 종합적 검토 및 면담}

의료기록 중 특히 이전 마취에서의 어려운 기도의 유무, 고 혈압, 당뇨, 고지혈증 등 각종 대사질환의 유무, 그리고 이전 에 시행한 수면검사가 있는지 확인한다. 나이, 성별, 비만도 등 신체계측도 확인한다. 수술 전 혈압, 맥박 및 산소포화도 등 활력징후도 확인한다. 환자와 가족 면담을 통해 이전에 $\mathrm{OSA}$ 증상이 있는지 확인하고, OSA가 예상되는 경우, 이에 상응하는 수술 후 예후의 위험성을 설명하고 예상되는 치료 방향에 대해서도 설명하여 협조를 구한다. 입원수술과 통원 수술을 결정할 수 있다면 환자 상태에 따라 안전하게 진행 할 수 있는 환경이 어느 쪽일지 종합적으로 판단하여 결정한 다. ${ }^{32}$ 고려해야 할 사항은 수면무호흡 상태, 해부학적 및 생 리적 이상, 동반 질환의 상태, 수술의 성격, 마취의 유형, 수술 후 아편유사제 사용 여부, 환자 연령, 퇴원 후 관찰의 적절성 및 외래 환자 시설의 능력 등이다.

가스교환(gas exchange)에 관련된 심각한 중증의 전신질 환이 없는 한, OSA가 의심되거나 진단받았다고 해서 수술을 미룰 필요는 없다. 단, 저호흡 증후군(hypo-ventilation syndrome), 중증 폐동맥 고혈압(severe pulmonary hypertension)이나 안정시 저산소혈증(resting hypoxemia) 등의 소견
을 보인다면 심혈관내과나 마취과 등 관련과에 협진하여 수 술 전 심혈관 및 호흡 기능을 안전하게 정상화시킬 시간이 필요하다. 이를 감별하기 위해 동맥혈 가스분석 검사를 실시 하여 안정시 저산소혈증(resting hypoxemia)이나 고탄산혈증 (hypercapnia) 유무 등을 파악한다. 정규수술이라면 수술 전 CPAP나 비침습적 양압환기(noninvasive positive pressure ventilation, NIPPV) 등을 통해 수술 전 상태를 최적화한 후 수술하는 것이 안전하다.

\section{신체검사 및 OSA 선별 평가}

수술 전 OSA 진단을 받고 오는 경우는 흔치 않으며, 수술 시 진단되지 않은 OSA의 유병률은 80 90\%나 된다. ${ }^{33}$ 수술 전 합병증에 대한 위험이 높아짐에 따라 OSA 환자의 수술 전 감별검사 및 평가에 관한 진료지침은 제공자 간의 인식을 높 이고 위험을 완화하기 위해 OSA 환자를 적절하게 식별하기 위한 검사를 시도해야 한다고 권장한다. ${ }^{31}$ 수면다원검사 등 OSA 진단을 위한 다양한 검사를 진행하지 않았다고 해서 수 술을 미루는 것은 권고되지 않고 있으므로, ${ }^{31}$ 많은 경우 OSA 선별검사결과와 수술 전 마취과 의사에 의한 기도평가에 의 존하게 된다. 선별검사로는 STOP-bang score, P-SAP, Berlin 설문지, and ASA Check List 등의 검사들이 있으며 최근 BOSTN score도 좋은 예측력으로 사용되고 있다. ${ }^{34}$ 가장 널 리 알려진 선별검사는 STOP-bang score이다. ${ }^{2}$ 점 이상에서 OSA 위험을 의심할 수 있는 양성으로 판정한다(Table 1). 그러나, STOP-bang score 3점 이상이 OSA 진단에 민감도 (83.6\%)는 크나 특이도(56.4\%)가 떨어지며, ${ }^{2}$ 동양인에게는 백 인 기준인 BMI $35 \mathrm{~kg} / \mathrm{m}^{2}$ 과 목둘레 $40 \mathrm{~cm}$ 가 적합하지 않은 경우가 많다. 또한, 한국인을 비롯한 동양인은 비만도가 떨 어져도 심각한 무호흡 증상을 보이는 경우가 많으며, 고혈압 이 있는 50세 이상 남성이라면 OSA 증상이 없거나 비만하지 않더라도 STOP-bang score 3점 이상을 가질 수 있으므로 선 별검사의 특이성은 떨어질 수밖에 없다. 이에 Seguin 등은, STOP-bang score 5 8인 경우에 STOP-bang score 3 4에 비 해 중등도 이상의 OSA를 시사하는 $\mathrm{AHI}>15$ 이상과 유의한 관련성(odds ratio 2.9)이 있다고 보고했다. ${ }^{35}$ 즉, 낮은 STOPbang score(3 4점)를 가진 환자들에서는 OSA 예측률을 증가

Table 1. Perioperative management for the patients with obstructive sleep apnea

\begin{tabular}{|c|c|c|c|}
\hline & Preoperative & Intraoperative & Postoperative \\
\hline Target & $\begin{array}{l}\text { Patient evaluation, consultation, and } \\
\text { preparation }\end{array}$ & $\begin{array}{l}\text { Selection of adequate anesthetic options } \\
\text { and effective anesthetic management }\end{array}$ & $\begin{array}{l}\text { Avoid airway obstruction and opioid } \\
\text { induced respiratory depression }\end{array}$ \\
\hline Methods & $\begin{array}{l}\text { OSA risk stratification and preoperative } \\
\text { optimization }\end{array}$ & $\begin{array}{l}\text { Monitoring \& preoxygenation } \\
\text { Secure airway and avoid hypoxemia } \\
\text { Safe recovery }\end{array}$ & Monitoring and detailed care \\
\hline
\end{tabular}


시키지 못했으며, 이런 환자군 모두에게 수술 전 수면검사를 권고하는 것은 바람직하지 않다는 의견을 보였다. 또한, 다 양한 환자군에서 변형된 STOP-bang score들이 소개되었고 향상된 진단율을 보였지만 여전히 한계가 있다(Table 2). ${ }^{36,37}$

한편, 새로운 선별검사 도구인 $\mathrm{BOSTN}$ 점수도 좋은 예측 력을 보여준다(Table 3). ${ }^{34}$ STOP-bang score에 비해 간략해 진 항목으로 쉽게 사용할 수 있는 장점이 있다. 사실상 무호 흡, 코골이, 그리고 낮시간 피로감 등 OSA 증상에 BMI 30 $\mathrm{kg} / \mathrm{m}^{2}$ 이상과 목둘레증가로 압축된 선별검사이다. 이중 2가 지 이상일 경우 양성 선별된다. STOP-bang score에 비해 $\mathrm{BMI}$ 는 $30 \mathrm{~kg} / \mathrm{m}^{2}$ 으로 낮아졌고, 목둘레의 기준은 여자 16.5 $\operatorname{inch}(41.9 \mathrm{~cm})$, 남자 $17.5 \mathrm{inch}(44.4 \mathrm{~cm})$ 로 증가했다. 한국인 의 평균 목둘레는 남성 $36 \mathrm{~cm}$, 여성 $33 \mathrm{~cm}$ 정도이며, 목둘레 증가는 중심비만이나 어려운 기도로 인한 변화를 반영하는 수치이며, 최근 당뇨나 다른 심혈관 질환과의 관련인자로도 많이 보고되고 있다. 반대로, OSA가 오히려 좋은 수술 후 예 후로 작용한다는 연구도 있다. Raub 등은 BOSTN score 2 이 상이나 STOP-bang score 5점 이상의 OSA 환자들이 수술 직후에는 저산소혈증 등의 위험이 있지만, 전체 입원기간도 짧고 수술 후 인공호흡기 사용도 적었다고 보고하였다. ${ }^{34}$ 한 달 내 재입원율도 유의하게 낮았음을 주장했다. 즉, 수술 후 일시적인 위험이 있지만, 이후에는 전체적으로 좋은 경과를 보인다는 것이다. OSA의 예후 및 치료효과에 대한 세심하게

Table 2. STOP-bang scores

\begin{tabular}{ll}
\hline \multicolumn{2}{c}{ Analyzed variable } \\
\hline $\mathrm{S}$ & Snoring \\
$\mathrm{T}$ & Tiredness \\
$\mathrm{O}$ & Observed apnea \\
$\mathrm{P}$ & High blood pressure \\
$\mathrm{B}$ & $\mathrm{BMI}>35 \mathrm{~kg} / \mathrm{m}^{2}$ \\
$\mathrm{~A}$ & Age $>50 \mathrm{y}$ \\
$\mathrm{N}$ & Neck circumference $>40 \mathrm{~cm}$ \\
$\mathrm{G}$ & Gender: male \\
\hline BMI: body mass index
\end{tabular}

Table 3. BOSTN scores

\begin{tabular}{ll}
\hline & \multicolumn{1}{c}{ Variables } \\
\hline $\mathrm{B}$ & $\mathrm{BMI} \geq 30 \mathrm{~kg} / \mathrm{m}^{2}$ \\
$\mathrm{O}$ & Observed apnea \\
$\mathrm{S}$ & Snoring that is loud \\
$\mathrm{T}$ & Tiredness in the daytime \\
$\mathrm{N}$ & Neck circumference $\geq 16.5$ inches in females or $\geq 17.5$ inches \\
& in males \\
\hline
\end{tabular}

BMI: body mass index
고안된 전향적 연구가 필요할 것으로 생각된다.

그 외

신체계측이나 설문지를 이용한 선별검사들은 널리 사용 되고 있으나, 민감도가 높은 데 반해 특이도가 낮아 예측되지 못한 어려운 기도를 초래할 수 있다. 예측하지 못한 어려운 기도의 경우 OSA 환자의 높은 비만도와 낮은 산소포화도로 인해 주술기 위험을 크게 상승시킬 수 있다. 수술 직전 기도 평가나 선별검사를 통해 발견된 OSA의 경우 이미 진단된 OSA 환자에 비해 오히려 높은 수술 후 기도 재삽관율과 인 공호흡기 거치율을 보이며 재원일수도 유의하게 길다고 보 고되었다. ${ }^{38}$ 또한, OSA 발생 빈도가 높지만 협조가 쉽지 않은 뇌혈관질환자나 장애인의 경우 이런 선별검사들을 시행할 수 없는 경우가 많다. 이에, 수술 직전 바로 시행할 수 있는 간단하며 예측력이 높은 검사로 초음파를 이용한 신체계측 (point of care ultrasonography, PoCUS)이 많이 보고되고 있다. 현재까지 인종에 따른 어려운 기도에 관한 다양한 지 표가 보고되고 있으며, 선별검사에 비해 높은 민감도와 특이 도를 지니는 장점이 있다. ${ }^{39}$ 기관전 지방(pretracheal fat), 피 부-갑상연골막 거리(skin to thyroid membrane), 피부-후두 개 거리(skin to epiglottis), 그리고 혀의 두께(tongue thickness) 등의 여러 지표들이 어려운 기도관리와 관련된 것으로 밝혀졌다. ${ }^{40,41}$ 앞으로 STOP-bang score 등과 함께 실제 임 상에서 많이 사용될 것으로 전망된다. ${ }^{42}$

\section{수술 전 준비(Preoperative preparation)}

수술 전 환자상태를 개선하거나 최적화하기 위한 것으로 CPAP나 NIPPV, 수술 전 하악 전진 기구(mandibular advancement device) 사용 및 수술 전 체중 감량이나 금연, 금 주 실천 등이다.

양압기 사용

심한 OSA로 심각한 합병증이 동반된 환자에서는 수술 전 부터 $\mathrm{CPAP}$ 를 거치하기를 권고한다. $\mathrm{CPAP}$ 에 적절하게 반응 하지 않는 환자의 경우 NIPPV를 고려해야 한다. CPAP는 착용의 불편함이라는 단점이 있지만, 심한 정도의 OSA에도 치료적 성과를 보일 수 있으며 주술기 합병증을 유의하게 줄 여줄 수 있는 것으로 알려져 있다. 수술 전 $\mathrm{CPAP}$ 를 사용하 던 환자들은 입원 시 본인의 $\mathrm{CPAP}$ 장비를 그대로 수술 후 까지 사용하면 된다.

\section{하악 전진 기구}

하악 전진 기구 등의 구강내 장치를 사용하는 경우 주술기 
합병증 위험을 줄일 수 있는지에 대한 근거는 충분하지 않 다. ${ }^{31}$ 그러나, 경증의 OSA에서는 $\mathrm{CPAP}$ 의 불편함을 피하기 위해 간단히 사용할 수 있으나, 심각한 OSA의 경우 그 효과 가 명확하지 않으며, 장기간 사용 시 교합 및 골격의 변화를 일으키거나 구강건조, 악관절의 약화 등을 일으킬 수 있으므 로 주의가 필요하다. ${ }^{43}$

\section{생활 습관 교정}

수술을 앞둔 환자들은 체중감소나 금주, 금연에 대한 교육 을 받아야 하며 이를 실천하도록 노력해야 한다. 비만도를 줄 이는 것은 OSA 정도를 줄이는 데 직접적으로 기여할 수 있 으나 그 효능을 평가하기에는 근거가 다소 부족하다. 금주나 금연으로 OSA를 악화시키는 인자를 배제해야 한다. ${ }^{31}$ 비만 은 그 자체로서 음식에 대한 구갈, 활동 감소, 체중 증가 및 OSA 심화 등 악순환이 되풀이되는 핵심 기전이므로 체중을 감량할 수 있는 다양한 방법이 장기적인 견지에서 시도되어 야 한다.

\section{수술 중 관리}

\section{마취방법 및 마취제 선택}

평소 수면 중 기도가 막히는 일이 잦은 OSA 환자는 수면 박탈과 기도 허탈(airway collapse) 등으로 마취제나 진정제 및 아편유사제에 의한 호흡억제에 매우 민감한 상태이다. 따 라서, 수술 중 마취제의 선택에 있어서 수술 후 호흡에 미칠 영향을 고려하는 것이 중요하다. ${ }^{31}$ 간단한 수술이나 표면적 시술일 경우 국소마취나 신경차단술 등의 국소적 마취를 가 능한 한 진정제를 투여하지 않고 시행한다. 중등도 진정이 필 요한 시술이나 부위마취 후 진정의 경우 기도 폐쇄나 호흡 억 제를 조기 발견하기 위해 맥박산소계측기(pulse oximeter)와 함께 날숨끝이산화탄소분압측정도를 모니터한다. 심한 코골 이나 반복되는 기도폐색과 무호흡이 방치되어서는 안되며, 일반적으로 진정(sedation) 중 고개를 돌리거나 목을 신전하 는 등으로 기도가 유지되지 않는 경우 nasopharyngeal airway 등으로 기도를 유지한다. 이전에 CPAP나 구강내 장치를 사 용하던 환자들은 그대로 사용할 수 있다. 깊은 진정이 필요한 시술을 시행할 경우 기도가 확보되기 힘든 깊은 진정을 하기 보다는 기도를 확보하는 전신마취를 안전하게 시행하는 것 이 권고된다. 사지 수술의 경우 전신마취보다는 척추마취나 경막외마취 등의 부위마취가 권고된다. 신경 차단술의 경우 수술 후 아편유사제 사용량도 줄일 수 있어 전신마취보다 주 술기 위험을 크게 감소시킬 수 있다.

\section{전신마취와 모니터링}

마취 직전 재평가를 통해 체중 변화 정도와 활력징후를 확 인한다. 최종 기도평가를 하며 어려운 기도에 대한 대비정도 를 확인한다. OSA가 진단되지 않았거나 기도평가에서 어려 운 기도로 판단되지 않았어도 OSA가 있는 비만환자의 경우 어려운 기도에 준하는 상태로 간주하고 준비해야 한다. 비만 환자들은 기저 산소포화도가 낮고 마스크 환기의 효율이 높 지 않다. 혹시 발생할 수 있는 "cannot ventilate cannot intubation"의 경우를 대비하여 수술실 입실과 함께 산소를 투여 하여 마취유도 전 충분한 시간 동안 전산소화(preoxygenation)한다. 산소를 투여할 시 자세는 앙와위보다는 상체를 높인 자세나 앉은 자세가 유리하다..$^{4}$ 무호흡 기간에도 apneic oxygenation이나 CPAP를 사용하여 불포화 정도를 최대한 낮추도록 한다. 마스크 환기와 기도삽관을 위해 필요한 기구 를 잘 준비해 두는 것이 안전하다. 위험이 예상될 경우 다른 한 명의 기도전문가를 입회시키고 마취를 진행한다. 기도 유 지에 필요한 다양한 기구들(oral and nasopharyngeal airway, supraglottic airway, video laryngoscope, lightwand, fiberoptic bronchoscope 등)을 이용하여 안전하게 삽관한다. 어 려운 기도인 경우 최근 업데이트된 어려운 기도에 대한 진료 지침에 따라 안전하게 대응한다. ${ }^{45}$

금기 사항이 없다면 환자의 의식이 회복되고 근이완제의 완전 역전을 확인한 후 발관하는 것이 안전하다. 근이완제의 완전한 역전을 위한 Sugammadex 등 특정 약물에 대한 선호 도의 근거는 아직 명확하지 않으나, 임상에서 위험환자를 대 상으로 널리 쓰이고 있다. 자발 호흡이 약할 경우 가능하다면 상체를 높인 자세나 옆으로 누운 자세에서 자발 호흡을 회복 시키는 것이 $\mathrm{FRC}$ 회복과 산소화에 도움이 된다. ${ }^{17}$ 필요할 경 우 CPAP를 유지하면서 호흡기(ventilator)의 압력보조모드 (pressure support mode)로 도움을 받아 자발호흡을 공고히 회복시키는 것도 안전한 대안 중 하나이다. 발관 후 호흡이 안정되면 head up 자세로 상체를 충분히 올리고 호흡을 확인 한 후 회복실로 안전하게 이송한다. 중증의 OSA 환자라면 가 까운 거리를 이동하더라도 산소를 공급하는 것이 선호된다.

\section{수술 후 관리}

수술 후 관리는 크게 수술 직후 회복관리, 병동 관리 및 퇴 원 관리 등으로 나눌 수 있다.

\section{수술 직후}

일반적으로 회복실이나 중환자실 등 수술 직후 회복기간 을 의미한다. 수술 후 완전히 의식이 회복되고 호흡이 안정 될 때까지 30분 1 시간 정도의 시간이다. 마취과 의사나 중 
환자실 담당 의사에 의해 면밀하게 감시되어야 하며, 대부분 의 경우 아편유사제를 필요로 하거나 자가 통증 조절기 등 연속 주입형 아편유사제를 사용하는 경우도 많아 OIRD의 위험이 크다. 또한, 마취제의 잔존효과가 남아 있어 진정제와 아편유사제를 함께 사용하는 효과를 가지는 시기이다. 근육 이완제 효과는 완전히 역전되어야 하며, 수술 후 폐합병증을 막기 위해 앙와위가 아닌 상체를 세운 자세를 취하는 것이 좋다. ${ }^{17,18} \mathrm{OSA}$ 환자나 의심 환자의 경우 비만하며 아편유사 제 등의 영향으로 고개가 떨구어져 기도가 막히는 경우가 발 생할 수 있으므로 특별히 주의를 기울여야 하며, 맥박 산소 계측기나 capnography 등의 연속 모니터를 필요로 한다. ${ }^{29}$ 적 정한 용량의 아편유사제를 처방하여야 하며, 기도가 자주 막 혀 산소 포화도가 떨어질 경우 수술 직후라면 턱 들어올리기 (jaw thrust) 등의 기도 확보 자세를 취해 주거나 비인두 기도 유지기(nasopharyngeal airway device) 등의 기구를 사용하 여 기도를 확보한다. ${ }^{46}$ 비인두 기도유지기는 마취과 의사들 에 의해 많이 사용되며, 진정진료 중이나 수술 직후 기도 폐 쇄를 막기 위해 코에 거치하여 사용한다. 구강 기도유지기 (oral airway)를 사용하기 어려운 의식이 있는 환자에서 구토 반사(gag reflex)를 거의 일으키지 않고 안전하게 사용할 수 있다. 치아가 좋지 않은 환자에서도 마찬가지로 안전하게 사 용할 수 있다. 그러나, 너무 좁은 내경일 경우 기도가 유지되 지 않고 막히게 되며, 적정한 크기를 사용하더라도 삽입할 때 통증이 심하고 출혈이 발생할 수 있으며, 거치 시에도 지속적 불편감이나 통증이 있어 수술 직후 일시적인 용도가 아니라 OSA 위험을 위해 평소에 일상적으로 사용하기는 쉽지 않 다. ${ }^{46}$ 그러나, 수술 후 24 시간 동안 기도 폐쇄의 위험이 큰 OSA 환자에서 수술 당일에 한해 사용하는 것은 OSA 환자 의 합병증 예방을 위한 간단하며 안전한 방법 중 하나일 수 있다. ${ }^{46}$

수술 후 충분한 시간이 흐르고 의식이 회복되어 협조가 되 더라도 아편유사제 투여 후나 잠이 든 상태에서는 OSA가 발생하거나 OIRD가 생길 위험이 있다. 특히, 정주성 아편유 사제를 사용할 경우 특히 주의하여야 한다. 자가 통증 조절 기(intravenous patient-controlled analgesia)가 사용될 경우 기저 주입(continuous infusion)이 없이 bolus loading 모드로 사용되는 것이 안전하며, 기저 주입이 있는 경우 호흡억제와 기도폐색에 대해 면밀히 모니터해야 한다. 퇴원이 예정되어 있다면 조금 더 회복기간을 가져야 한다. 특히 외래마취 후 퇴원이 예정된 환자라면 완전히 잠든 상태에서도 기도 폐쇄 가 되지 않으며 저산소혈증이 생기지 않음을 확인해야 하며, 이러한 확인이 없는 상태에서는 퇴원의 위험성에 대해 자세 히 설명하고 24시간 재원을 권유하는 것이 안전하다. ${ }^{32}$

\section{수술 후 병동}

수술 당일 특히 밤에 수면이 이루어지는 시간 동안이 OSA 환자에서 가장 위험한 시기이다. 근무 인원은 적고, 환자들은 모두 수면 중이므로 환자 감시가 가장 소홀해질 위험이 있다. 외국인이나 프라이버시를 위해 1 인실 등의 병실로 퇴실한 경 우 모니터를 하더라도 자주 환자상태를 확인하여야 하며, 연 속 모니터링이 되는 병실로의 이동이 필요할 수도 있다. 수 면상태에서 산소공급 없이도 산소포화도를 유지할 정도로 회복될 때까지 OSA 환자들에게는 산소를 공급하는 것이 안 전하다. 기존에 $\mathrm{CPAP}$ 등 보조기구를 사용하던 환자는 자신 의 기구를 그대로 사용하며, $\mathrm{CPAP}$ 를 사용하지 않았던 환자 라도 수술 후 24시간 동안 가장 합병증이 많이 발생함을 환 자와 보호자에 인식시키고, 안전한 회복이 될 수 있도록 산 소포화도를 연속 모니터한다. Capnography를 함께 보는 것 도 무호흡을 일찍 진단할 수 있어 유용하다. ${ }^{29}$ 구강내 장치나 비인두 기도유지기를 사용하는 것도 일시적으로 효과적이 다. 구강내 장치는 수술 전 사용하던 기구가 있는 경우 계속 사용할 수 있다.

\section{결 론}

고령화와 비만인구 증가로 위험한 OSA를 동반한 환자들 에 대한 수술이 급증하고 있다. 이 환자들은 저산소혈증과 어 려운 기도유지 및 수술 후 호흡억제 위험 등과 함께 여러 수 술 후 합병증들로 생명을 위협받고 있다. OSA 환자의 병태 생리와 위험에 대해 정확히 인지하며, 안전한 기도확보와 면 밀한 환자감시 및 철저한 저산소혈증에 대한 대비를 통해 안 전한 주술기 관리를 이루어야 할 것이다.

\section{Acknowledgments}

None.

\section{Conflicts of Interest}

The authors have no potential conflicts of interest to disclose.

\section{ORCID iDs}

$\begin{array}{ll}\text { Jeong Heon Park } & \text { https://orcid.org/0000-0003-3852-5390 } \\ \text { Min A Kwon } & \text { https://orcid.org/0000-0002-7253-3768 }\end{array}$

Min A Kwon https://orcid.org/0000-0002-7253-3768

\section{Author Contributions}

Conceptualization: Min A Kwon. Data curation: Min A Kwon. Formal analysis: Min A Kwon. Funding acquisition: Min A Kwon. Investigation: Min A Kwon. Methodology: Min A Kwon. Project administration: Min A Kwon. Resources: Min A Kwon. Software: Min A Kwon. Supervision: Jeong Heon Park, Min A Kwon. Validation: Min A Kwon. Visualization: Min A Kwon. Writing—original draft: Min A Kwon. Writing—review \& editing: Jeong Heon Park, Min A Kwon. 


\section{REFERENCES}

1. Adesanya AO, Lee W, Greilich NB, Joshi GP. Perioperative management of obstructive sleep apnea. Chest 2010;138:1489-1498. https://doi. org/10.1378/chest.10-1108.

2. Chung F, Yegneswaran B, Liao P, et al. STOP questionnaire: a tool to screen patients for obstructive sleep apnea. Anesthesiology 2008;108: 812-821. https://doi.org/10.1097/ALN.0b013e31816d83e4.

3. Sunwoo JS, Hwangbo Y, Kim WJ, Chu MK, Yun CH, Yang KI. Prevalence, sleep characteristics, and comorbidities in a population at high risk for obstructive sleep apnea: a nationwide questionnaire study in South Korea. PLoS One 2018;13:e0193549. https://doi.org/10.1371/ journal.pone.0193549.

4. Gupta K, Prasad A, Nagappa M, Wong J, Abrahamyan L, Chung FF. Risk factors for opioid-induced respiratory depression and failure to rescue: a review. Curr Opin Anaesthesiol 2018;31:110-119. https://doi. org/10.1097/ACO.0000000000000541.

5. Chan MTV, Wang CY, Seet E, et al. Association of unrecognized obstructive sleep apnea with postoperative cardiovascular events in patients undergoing major noncardiac surgery. JAMA 2019;321:17881798. https://doi.org/10.1001/jama.2019.4783.

6. Fouladpour N, Jesudoss R, Bolden N, Shaman Z, Auckley D. Perioperative complications in obstructive sleep apnea patients undergoing surgery: a review of the legal literature. Anesth Analg 2016;122:145-151. https://doi.org/10.1213/ANE.0000000000000841.

7. Huang HH, Lee MS, Shih YL, Chu HC, Huang TY, Hsieh TY. Modified Mallampati classification as a clinical predictor of peroral esophagogastroduodenoscopy tolerance. BMC Gastroenterol 2011;11:12. https:// doi.org/10.1186/1471-230X-11-12.

8. Moon TS, Fox PE, Somasundaram A, et al. The influence of morbid obesity on difficult intubation and difficult mask ventilation. J Anesth 2019;33:96-102. https://doi.org/10.1007/s00540-018-2592-7.

9. Kheterpal S, Han R, Tremper KK, et al. Incidence and predictors of difficult and impossible mask ventilation. Anesthesiology 2006;105:885891. https://doi.org/10.1097/00000542-200611000-00007.

10. Shah PN, Sundaram V. Incidence and predictors of difficult mask ventilation and intubation. J Anaesthesiol Clin Pharmacol 2012;28:451455. https://doi.org/10.4103/0970-9185.101901.

11. Kheterpal S, Healy D, Aziz MF, et al. Incidence, predictors, and outcome of difficult mask ventilation combined with difficult laryngoscopy: a report from the multicenter perioperative outcomes group. Anesthesiology 2013;119:1360-1369. https://doi.org/10.1097/ALN.0000435832.39353.20.

12. Neligan PJ, Porter S, Max B, Malhotra G, Greenblatt EP, Ochroch EA. Obstructive sleep apnea is not a risk factor for difficult intubation in morbidly obese patients. Anesth Analg 2009;109:1182-1186. https://doi. org/10.1213/ane.0b013e3181b12a0c.

13. Brodsky JB, Lemmens HJ, Brock-Utne JG, Vierra M, Saidman LJ. Morbid obesity and tracheal intubation. Anesth Analg 2002;94:732-736; table of contents. https://doi.org/10.1097/00000539-200203000-00047.

14. Toshniwal G, McKelvey GM, Wang H. STOP-Bang and prediction of difficult airway in obese patients. J Clin Anesth 2014;26:360-367. https://doi.org/10.1016/j.jclinane.2014.01.010.

15. Gupta K, Nagappa M, Prasad A, et al. Risk factors for opioid-induced respiratory depression in surgical patients: a systematic review and meta-analyses. BMJ Open 2018;8:e024086. https://doi.org/10.1136/ bmjopen-2018-024086.

16. Jones RL, Nzekwu MM. The effects of Body Mass Index on lung volumes. Chest 2006;130:827-833. https://doi.org/10.1378/chest.130.3.827.

17. Itasaka Y, Miyazaki S, Ishikawa K, Togawa K. The influence of sleep position and obesity on sleep apnea. Psychiatry Clin Neurosci 2000;54: 340-341. https://doi.org/10.1046/j.1440-1819.2000.00705.x.

18. Dunham CM, Hileman BM, Hutchinson AE, Chance EA, Huang GS. Perioperative hypoxemia is common with horizontal positioning during general anesthesia and is associated with major adverse outcomes: a retrospective study of consecutive patients. BMC Anesthesiol 2014;14:
43. https://doi.org/10.1186/1471-2253-14-43.

19. Memtsoudis SG, Besculides MC, Mazumdar M. A rude awakening-the perioperative sleep apnea epidemic. N Engl J Med 2013;368:23522353. https://doi.org/10.1056/NEJMp1302941.

20. Drager LF, Polotsky VY, O’Donnell CP, Cravo SL, Lorenzi-Filho G, Machado BH. Translational approaches to understanding metabolic dysfunction and cardiovascular consequences of obstructive sleep apnea. Am J Physiol Heart Circ Physiol 2015;309:H1101-H1111. https:// doi.org/10.1152/ajpheart.00094.2015.

21. Mörwald EE, Olson A, Cozowicz C, Poeran J, Mazumdar M, Memtsoudis SG. Association of opioid prescription and perioperative complications in obstructive sleep apnea patients undergoing total joint arthroplasties. Sleep Breath 2018;22:115-121. https://doi.org/10.1007/ s11325-017-1539-9.

22. Dong R, Dong Z, Liu H, Shi F, Du J. Prevalence, risk factors, outcomes, and treatment of obstructive sleep apnea in patients with cerebrovascular disease: a systematic review. J Stroke Cerebrovasc Dis 2018;27: 1471-1480. https://doi.org/10.1016/j.jstrokecerebrovasdis.2017.12.048.

23. Bernards CM, Knowlton SL, Schmidt DF, et al. Respiratory and sleep effects of remifentanil in volunteers with moderate obstructive sleep apnea. Anesthesiology 2009;110:41-49. https://doi.org/10.1097/ALN. 0b013e318190b501.

24. Chung F, Liao P, Elsaid H, Shapiro CM, Kang W. Factors associated with postoperative exacerbation of sleep-disordered breathing. Anesthesiology 2014;120:299-311. https://doi.org/10.1097/ALN.0000000000000041.

25. Subramani Y, Nagappa M, Wong J, Patra J, Chung F. Death or neardeath in patients with obstructive sleep apnoea: a compendium of case reports of critical complications. Br J Anaesth 2017;119:885-899. https:// doi.org/10.1093/bja/aex341.

26. de Raaff CAL, Gorter-Stam MAW, de Vries N, et al. Perioperative management of obstructive sleep apnea in bariatric surgery: a consensus guideline. Surg Obes Relat Dis 2017;13:1095-1109. https://doi.org/ 10.1016/j.soard.2017.03.022.

27. Cozowicz C, Olson A, Poeran J, et al. Opioid prescription levels and postoperative outcomes in orthopedic surgery. Pain 2017;158:24222430. https://doi.org/10.1097/j.pain.0000000000001047.

28. Bolden N, Posner KL, Domino KB, et al. Postoperative critical events associated with obstructive sleep apnea: results from the society of anesthesia and sleep medicine obstructive sleep apnea registry. Anesth Analg 2020;131:1032-1041. https://doi.org/10.1213/ANE.0000000000005005.

29. Khanna AK, Bergese SD, Jungquist CR, et al. Prediction of opioid-induced respiratory depression on inpatient wards using continuous capnography and oximetry: an international prospective, observational trial. Anesth Analg 2020;131:1012-1024. https://doi.org/10.1213/ ANE.0000000000004788.

30. Lam T, Nagappa M, Wong J, Singh M, Wong D, Chung F. Continuous pulse oximetry and capnography monitoring for postoperative respiratory depression and adverse events: a systematic review and metaanalysis. Anesth Analg 2017;125:2019-2029. https://doi.org/10.1213/ ANE.0000000000002557.

31. American Society of Anesthesiologists. Practice guidelines for the perioperative management of patients with obstructive sleep apnea: an updated report by the American Society of Anesthesiologists Task Force on perioperative management of patients with obstructive sleep apnea. Anesthesiology 2014;120:268-286. https://doi.org/10.1097/ALN.0000000000000053.

32. Joshi GP, Ankichetty SP, Gan TJ, Chung F. Society for Ambulatory Anesthesia consensus statement on preoperative selection of adult patients with obstructive sleep apnea scheduled for ambulatory surgery. Anesth Analg 2012;115:1060-1068. https://doi.org/10.1213/ANE.0b013e318269cfd7.

33. Singh M, Liao P, Kobah S, Wijeysundera DN, Shapiro C, Chung F. Proportion of surgical patients with undiagnosed obstructive sleep apnoea. Br J Anaesth 2013;110:629-636. https://doi.org/10.1093/bja/aes465.

34. Raub D, Santer P, Nabel S, et al. BOSTN bundle intervention for perioperative screening and management of patients with suspected obstructive sleep apnea: a hospital registry study. Anesth Analg 2020;130: 
1415-1424. https://doi.org/10.1213/ANE.0000000000004294.

35. Seguin L, Tamisier R, Deletombe B, Lopez M, Pepin JL, Payen JF. Preoperative screening for obstructive sleep apnea using alternative scoring models of the sleep tiredness observed pressure-body mass index age neck circumference gender questionnaire: an external validation. Anesth Analg 2020;131:1025-1031. https://doi.org/10.1213/ANE.0000000000004909.

36. Boulos MI, Colelli DR, Vaccarino SR, Kamra M, Murray BJ, Swartz RH. Using a modified version of the "STOP-BANG" questionnaire and nocturnal oxygen desaturation to predict obstructive sleep apnea after stroke or TIA. Sleep Med 2019;56:177-183. https://doi.org/10.1016/ j.sleep.2018.12.021.

37. Combs D, Goodwin JL, Quan SF, Morgan WJ, Parthasarathy S. Modified STOP-Bang tool for stratifying obstructive sleep apnea risk in adolescent children. PLoS One 2015;10:e0142242. https://doi.org/10.1371/ journal.pone.0142242.

38. Fernandez-Bustamante A, Bartels K, Clavijo C, et al. Preoperatively screened obstructive sleep apnea is associated with worse postoperative outcomes than previously diagnosed obstructive sleep apnea. Anesth Analg 2017;125:593-602. https://doi.org/10.1213/ANE.0000000000002241.

39. Ni H, Guan C, He G, Bao Y, Shi D, Zhu Y. Ultrasound measurement of laryngeal structures in the parasagittal plane for the prediction of difficult laryngoscopies in Chinese adults. BMC Anesthesiol 2020;20:134. https://doi.org/10.1186/s12871-020-01053-3.

40. Pinto J, Cordeiro L, Pereira C, Gama R, Fernandes HL, Assunção J. Predicting difficult laryngoscopy using ultrasound measurement of distance from skin to epiglottis. J Crit Care 2016;33:26-31. https://doi. org/10.1016/j.jcrc.2016.01.029.

41. Singh M, Tuteja A, Wong DT, et al. Point-of-care ultrasound for obstructive sleep apnea screening: are we there yet? A systematic review and meta-analysis. Anesth Analg 2019;129:1673-1691. https://doi.org/ 10.1213/ANE.0000000000004350.

42. Yao W, Wang B. Can tongue thickness measured by ultrasonography predict difficult tracheal intubation? Br J Anaesth 2017;118:601-609. https://doi.org/10.1093/bja/aex051.

43. Park KJ, Kim ST. Long-term side effects of mandibular advancement devices in patients with obstructive sleep apnea. J Sleep Med 2019;16: 67-70. https://doi.org/10.13078/jsm.190025.

44. Shah U, Wong J, Wong DT, Chung F. Preoxygenation and intraoperative ventilation strategies in obese patients: a comprehensive review. Curr Opin Anaesthesiol 2016;29:109-118. https://doi.org/10.1097/ ACO.0000000000000267.

45. Apfelbaum JL, Hagberg CA, Caplan RA, et al. Practice guidelines for management of the difficult airway: an updated report by the American Society of Anesthesiologists Task Force on management of the difficult airway. Anesthesiology 2013;118:251-270. https://doi.org/10.1097/ ALN.0b013e31827773b2.

46. Camacho M, Chang ET, Fernandez-Salvador C, Capasso R. Treatment of snoring with a nasopharyngeal airway tube. Case Rep Med 2016; 2016:3628716. https://doi.org/10.1155/2016/3628716. 